This is an Accepted Manuscript of an article published by Taylor \& Francis in Oxford German Studies on 15 April 2016, available online: http://dx.doi.org/10.1080/00787191.2015.1128648

\title{
Split Infinities: German Feminisms and the Generational Project
}

\author{
Birgit Mikus, University of Oxford \\ Emily Spiers, St Andrews University
}

When, in the middle of the nineteenth century, the German women's movement took off, female activists/writers expressed a desire for their political work to initiate a generational project. The achievement of equal democratic rights for men and women was perceived to be a process in which the 'democratic spirit' was instilled in future generations through education and the provision of exceptional role models. The First Wave of the women's movement laid the ground, through their writing, campaigning, and petitioning, for the eventual success of obtaining women's suffrage and sending female, elected representatives to the Reichstag in 1919. My part of this article, drawing on the essays by Hedwig Dohm (1831-1919) analyses how the idea of women's political and social emancipation is phrased in the rhetoric of a generational project which will, in the short term, bring only minor changes to the status quo but which will enable future generations to build on the foundations of the (heterogeneous, but mostly bourgeoisie-based) first organised German women's movement, and which was intended to function as a generational repository of women's intellectual history.

When, in the mid-2000s, a number of pop-feminist essayistic volumes appeared in Germany, their authors expressed the desire to reinvigorate feminism for a new generation of young women. Their texts focus in part on the continuing need to ensure equal democratic rights for young women in terms of equal pay, reproductive capacities and child care. Yet they simultaneously register their dissatisfaction with the legacy of the New Feminism and, more specifically, with the role models it produced. Although in their written interventions these new German pop-feminists often draw on the generic and rhetorical strategies of their feminist forebears, they employ the generational metaphor as a means of producing a narrative of 'progress' (Hemmings, 2011) which signifies a departure from previous feminist discourses and firmly 'others' their exponents. This type of narrative resonates troublingly with wider social and political narratives which situate feminism firmly in the past. Strikingly, German pop-feminist volumes share the deployment of this progress narrative with similar publications in Britain and the US. Yet the German volumes generally - and uniquely in relation to those three contexts - avoid textual engagement with the writing and protagonists of the first women's movement in Germany. This section of the article examines the feminist historiographical narratives told in pop-feminist volumes across all three contexts, enquiring after the local specificities of generational thinking, its caesurae, emphases and omissions, and revealing the broader transnational commonalities - and political implications - of feminist stories. 
Keywords: Hedwig Dohm, Intellectual History, Nineteenth-century Feminism, Popfeminism, Second-wave Feminism, Generation, Narrative

\section{THE FIRST WAVE}

This section of the article outlines the common rhetoric of the German women's movement in the second half of the nineteenth century when conceptualizing itself as a generational project. From the very start, the founders and figureheads of the various political and social factions of the women's movement looked toward the future as the place where all of their demands, hopes and dreams would be fulfilled, true equality between the sexes achieved, and women independent and self-determined beings. This is an optimism shared by all groups in the women's movement regardless of their political stance or party alignment, and which finds its expression implicitly or explicitly in many texts of that time. While some authors like Matilde Franziska Anneke and Malwida von Meysenbug rhetorically place their confidence in mothers and their education of the next generation, ${ }^{1}$ other activists such as Louise Otto-Peters speak of their 'prophecies' for a shining future for the women of the coming generations. ${ }^{2}$ Hedwig Dohm is the one who formulates the idea of the women's movement explicitly as a generation-spanning endeavour, writing at the end of the nineteenth century as a contemporary commentator on the German women's movement up to this point.

When writing historically about the German women's movement today, it is necessary to make explicit the two differing viewpoints, if not world views, that have developed since then in German feminism. As Ann Taylor Allen, among others, has pointed out frequently, nineteenth-century feminism was fundamentally different to twentieth- and twenty-first-century feminism in Germany, in that the former proclaimed an essential difference between men and women (often abbreviated to the formula 'different but equal'), and the latter argues with essential sameness of the two. ${ }^{3}$ Both arguments are inherently logical and coherent, both have their respective pitfalls and shortcomings. From a modern

\footnotetext{
${ }^{1}$ See Birgit Mikus, 'Children of the Revolution? A Case Study of the Missing Next Generation in Women's Political Writings in the Nineteenth Century and Hedwig Dohm’s Novels’, German Life and Letters, 67 (2014), pp. 542-54.

${ }^{2}$ See e.g. Louise Otto-Peters, Frauenleben im Deutschen Reich: Erinnerungen aus der Vergangenheit mit Hinweis auf Gegenwart und Zukunft (Leipzig: Schäfer, 1876).

${ }^{3}$ Ann Taylor Allen, Feminism and Motherhood in Germany, 1800-1914 (New Brunswick, NJ: Rutgers University Press, 1991).
} 
point of view, the insistence on an essential female nature different from an essential male nature appears as an outrageous biological determinism, as a logical and conceptual cul de sac in the fight for equal legal rights and emancipation for women. On the other hand, one can argue that the assumption of an essential sameness of male and female implicitly acknowledges the (current) status of the male as the norm, since most arguments in this form of feminism are based on the notion that women still have to 'achieve' the 'same level' in social or workplace hierarchies, implying a necessity to 'draw equal' in some form or the other, making the postulated male advantage as the perceived goal to reach. This paper is not concerned with arguing either side of this debate; however, this short summary is necessary as a conceptual framework when analysing texts historically, and it is crucial to be precise when establishing and locating one's own analytical framework in the feminist discourse. As Allen points out, the schools of thought of the twentieth century, e.g. historians such as Richard J. Evans, mostly investigate nineteenth-century feminism through the lens of modern egalitarian feminism, thereby coming to the conclusion that it was hopelessly stuck in naturalistic rhetoric, biological determinism, and open to exploitation by the dominant patriarchal discourse, if not actively (though perhaps unwittingly) reinforcing it. ${ }^{4}$ However, historians such as Allen herself and Edward Ross Dickinson have begun to investigate the same texts and political activists against the background of the historical 'different but equal' feminism, and as a result have uncovered the sophistication and radicalism of the debates of the First Wave. ${ }^{5}$

Towards the end of the nineteenth and the beginning of the twentieth centuries, the term 'generation' was decidedly more loaded with connotations and references to contemporary discourses as it is now. As Allen has pointed out, in the wake of Charles Darwin and Ernst Haeckel, the concept of eugenics was developed by the British biologist Francis Galton in the 1880s. ${ }^{6}$ This concept presupposed that, simply speaking, since humans had (some) conscious influence on whether or not to have offspring, they were able to influence the course of natural selection, thereby steering humanity towards a better, healthier populace. Allen analyses how this discourse had major influence on the feminist movement in Germany at that time: since most people who discussed and defined this discourse, namely

\footnotetext{
${ }^{4}$ Allen, Feminism and Motherhood in Germany, 1800-1914; Richard J. Evans, The Feminist Movement in Germany, 1894-1933, Sage Studies in 20th Century History, 9 vols (London: Sage, 1974-1979), VI (1976).

${ }^{5}$ Edward Ross Dickinson, 'Reflections on Feminism and Monism in the Kaiserreich, 1900-1913', Central European History, 34 (2001), pp. 191-230.

${ }^{6}$ See Ann Taylor Allen, 'Feminismus und Eugenik, im historischen Kontext', Feministische Studien, 9 (1991), p. 48.
} 
in terms of society's and the state's control of motherhood, were men, it was of the utmost importance and interest to the feminist movement to develop their own stance and definitions in order to escape objectification and control of their bodies as mere optimized birthing vessels of the future nation. Therefore, the moderate wing of the bourgeois women's movement developed the strategy to think of motherhood not only as a physical process but also as an abstract, spiritual one, designed to help women both to escape the biological reduction that their only contribution to society and the nation could be children, and make it possible for all women, married or unmarried, with children but especially without, to focus their work elsewhere in the public sphere. This feminist discourse of 'spiritual motherhood' and 'extended motherliness' has been analysed in detail by Allen and Charlotte Woodford, and will be understood as the historical and ideological backdrop for this section of the article. $^{7}$ In the 1900s, the German women's movement underwent the first conceptual shift in the motherhood discourse. As Dickinson has pointed out, the earlier, moderate feminists employed the concept of motherhood as a spiritual, abstract idea, whereas the 'second generation' of more radical feminists in the 1900s onwards went in the opposite direction: they employed the experience of physical motherhood and the terminology of eugenics in order to campaign for sexual education and the right to contraception and abortion. ${ }^{8}$ The use of eugenic arguments prevalent in the earlier discourse of radical feminists seems disturbing today, although it is important to remember that such positions were widely held on the left in Britain and Germany at that time. Although Peter Davies points out in this context that 'there was no direct route from turn of the century eugenic language to National Socialism, but instead what Atina Grossmann calls a "convoluted and highly contested route", ${ }^{9}$ it is still haunting and difficult to read these arguments today without thinking of the devastating eugenic programmes of the Nazis. This is very likely a major factor in today's feminists' unwillingness to engage with the political programmes of the First Wave (which Emily Spiers analyses in more detail in the second section of this article), although they share topics and concerns such as the economic situation of single mothers, or access to freely available and legal abortion, an issue which became of particular importance to Weimar feminists.

\footnotetext{
${ }^{7}$ Allen, Feminism and Motherhood in Germany, 1800-1914. Charlotte Woodford, Women, Emancipation and the German Novel 1871-1910: Protest Fiction in Its Cultural Context, Germanic Literatures, 12 vols (London: Legenda, 2013-), VI (2014).

${ }^{8}$ Dickinson, 'Reflections on Feminism and Monism in the Kaiserreich, 1900-1913'.

${ }^{9}$ Peter Davies, Myth, Matriarchy and Modernity: Johann Jakob Bachofen in German Culture, 1860-1945, Interdisciplinary German Cultural Studies (New York: De Gruyter, 2010), p. 119. Citing Atina Grossmann, Reforming Sex: The German Movement for Birth Control and Abortion Reform, 1920-1950 (Oxford; New York: Oxford University Press, 1995), p. vii.
} 
In this historical context, it makes perfect sense for bourgeois feminists to formulate their aspirations and intentions for the women's movement in the terms of a generational project. On the one hand, it was obvious that the legal and political changes these feminists demanded would need time to achieve, as well as the changes in social and individual attitudes towards women's roles in society and the state. On the other hand, it was also a programmatic stance in the framework of the contemporary concept of history as well as the formation of the nation state: since the dominant model of history was that of perpetual progress towards a higher manifestation of humanity, it was almost inevitable that women's legal position would change for the better, too, provided there were always people willing to fight their corner:

Die Männer der strengsten Wissenschaft lehren uns, daß das Lebensprincip aller Geschichte nichts anderes sei als die Entwickelung zur Freiheit, und darum ist die Sache der Frauen die Sache der gesammten Menschheit, und so wahr es einen Fortschritt giebt, so gewiß müssen wir siegen. ${ }^{10}$

The ideal nation state, as envisaged by most of the bourgeois populace at that time, would depend on enfranchised, equal citizens, and not least on the legal and social standing of mothers in this state.

One author who used this line of argument most explicitly is Hedwig Dohm (18311919) who belonged to the more radical faction of the bourgeois women's movement. In her texts she very clearly combines both the concept of abstract motherhood, in particular of the women's movement as an intellectual legacy throughout the generations, and the radical demands for women's bodily and sexual autonomy both in- and outside of physical motherhood. In her essays as well as her novels, Dohm portrays the women's movement as something explicitly directed into the future when she says 'In der Frauenfrage, wie in allen großen socialen Fragen, gilt es nicht, festzustellen, was war und was ist, sondern was sein wird. ${ }^{11}$ This trajectory is always present, in contrast to e.g. Louise Otto-Peters's rhetorical tactic of always comparing the situation of women a few decades before to the achievements they have pushed through already, in order to illustrate that change is indeed possible. While Otto-Peters is very much concerned with the status of women in the (her) here and now,

\footnotetext{
${ }^{10}$ Dohm, Der Jesuitismus im Hausstande. Ein Beitrag zur Frauenfrage (Berlin: Wedekind \& Schwieger, 1873), p. 226.

${ }^{11}$ Dohm: Die wissenschaftliche Emancipation der Frau (Berlin: Wedekind \& Schwieger, 1874), pp. 165-66 (see CD-ROM Deutsche Literatur von Frauen, p. 15968).
} 
Dohm makes very clear that, no matter what has already been achieved, the improvement towards full equality of women will take the work and the time of the generations to come:

Sie glauben, und mit Ihnen die Majorität der Männer, daß Gott und die Naturgesetze in der Frauenfrage längst entschieden haben; ich aber meine, daß der bewußte Kampf erst beginnt, und daß er nur enden wird, wenn die Frau das allen menschlichen Wesen angeborene Recht erobert hat: Mensch zu sein. ${ }^{12}$

Dohm is also very much aware of the different positions inside the women's movement; however, instead of describing them as opposing ideologies or fighting for opposing goals, she puts political directives on a timeline, justifying her argument by quoting Ferdinand Lasalle:

In der heutigen Frauenbewegung vertritt die Rechte die praktische Seite, das augenblicklich Erreichbare. Die Linke zeigt die Ziele der Bewegung in der Zukunft.

"Eine theoretische Leistung ist um so besser, je vollständiger sie alle, auch die letzten und entferntesten Konsequenzen des in ihr entwickelten Prinzips zieht. Eine praktische Leistung ist um so mächtiger, je mehr sie sich auf den ersten Punkt konzentriert, aus dem alles weitere folgt.” (Lassalle.) ${ }^{13}$

With the Lassalle quotation it becomes clear that Dohm sees the necessity for both: the ability to recognize and work for the things which are achievable in the near future, and the theoretical, intellectual framework which ensures the continuation of the political and social discourse. It is this intellectual framework which lies at the heart of Dohm's concept of generations as the vehicle for the future of the women's movement: not only the political struggle and the actual political changes form the legacy of the women's movement but the awareness of both the history of feminism and the implications of the formations of a feminist theory. Isabel Rohner points out the programmatic aspect of Dohm's interest in a feminist intellectual tradition:

[...D]ie Autorin [weist] nicht nur auf die mangelhafte Mädchenbildung hin, sondern auch auf die damit verbundene Traditionslosigkeit der Frauen in puncto Bildung: Durch den Ausschluss aus dem Bildungs-Kanon wird ihnen nicht nur der Zugang zum

\footnotetext{
${ }^{12}$ Dohm: Die wissenschaftliche Emancipation der Frau, p. 183 (see CD-ROM Deutsche Literatur von Frauen, p. 15984).

${ }^{13}$ Dohm: Die Antifeministen. Ein Buch der Verteidigung (Berlin: Ferdinand Dümmlers Verlagsbuchhandlung, 1902), pp. 9-10 (see CD-ROM Deutsche Literatur von Frauen, p. 16175).
} 
männlichen Wissensfundus verwehrt, sondern auch die Möglichkeit einer eigenen Denktradition. Wie zentral diese Erkenntnis für Dohm ist, macht ein Blick auf ihr Gesamtwerk deutlich, wo sie immer wieder vorführt, wie wichtig Denktraditionen sind und dass Erkenntnis nicht aus sich heraus kommen kann, sondern auf dem Verstehen und Weiterdenken von bereits Bestehendem beruht[.] ${ }^{14}$

It is this 'tradition of thought' that Dohm phrases in terms of generations of women realising the aims and goals of the German feminists in the second half of the nineteenth century.

While this intellectual programme is more or less implicit in her essays, Dohm was more explicit about a generational project in conceptualising her trilogy of novels as a series of generations. In her 'Selbstanzeige' for the novel Sibilla Dalmar, she famously described the novels as following the lives of grandmother (Schicksale einer Seele, 1899), ${ }^{15}$ daughter (Sibilla Dalmar, 1896) ${ }^{16}$, and granddaughter (Christa Ruland, 1902), ${ }^{17}$ thereby tracing the development of three generations. In the last novel, an essay one of the female characters reads out to friends constitutes probably the most quoted passage of all the three novels. Dohm condenses here the problems this granddaughter's generation faces, not only in society or in politics, but in their own struggle for orientation in a world slowly opening to new opportunities:

Es ist ein Zwiespalt in uns Werdenden zwischen dem Altererbten und dem Neuerrungenen. Was seit so vielen Generationen Recht und Brauch war, hat sich unserer Gesinnung einverleibt, es ist beinah Instinkt bei uns geworden. Wir haben noch die Nerven der alten Generation und die Intelligenz und den Willen der neuen. ${ }^{18}$

In the essay, famously titled 'Übergangsgeschöpfe', Maria Hull, a chemist described as a "Neue Frau”, categorizes her own generation of women according to their motivations and reasons for entering non-traditional fields, such as employment and research in all kinds of forms, the arts, and politics. One group especially is unmistakeably coined in favour of the women's movement and imbued with Dohm's characteristic futurity:

\footnotetext{
${ }^{14}$ Isabel Rohner, In Literis Veritas. Hedwig Dohm und die Problematik der fiktiven Biographie (Berlin: trafo, 2008), p. 152.

${ }^{15}$ Hedwig Dohm, Schicksale einer Seele (Berlin: trafo, 2007).

${ }^{16}$ Hedwig Dohm, Sibilla Dalmar: Roman aus dem Ende unseres Jahrhunderts (Berlin: trafo, 2006).

${ }^{17}$ Hedwig Dohm, Christa Ruland (Berlin: trafo, 2008).

${ }^{18}$ Dohm, Christa Ruland, p. 124.
} 
Von den neuen jungen Mädchen will ich reden. Es gibt unter dieser vorwärtsdrängenden weiblichen Jugend sehr verschiedene Kategorien. [...] Eine andere bedeutsame Kategorie bilden die mit Energie, Tatkraft, Wirklichkeitssinn Ausgestatteten, die erkannt haben, daß die Macht der Weg ist, der zum Ziel führt. Das sind die Agitatorinnen, das sind die Rednerinnen auf den Tribünen, in Vereinen, Volksversammlungen. Es sind die Ruferinnen im Streit. Heut Kämpferinnen, werden sie morgen Siegerinnen sein. [...]

Wir alle, wir erleben nicht die Zeit, wo die Kometen sich zu Sternen verdichten, wo die Schwarmgeister sich ansiedeln werden. Auf der Schwelle des gelobten Landes werden wir wie Moses sterben. Aber auch gleich dem Moses haben wir hungernde Scharen durch die Wüste bis an die Tore des Neulandes geführt. Ob Moses zufrieden starb $?^{19}$

The explicit rhetorical reference to categories and to Moses in the sense of a founding father, the origin of a myth-building process, imply not only the continued political fight for the women's movement in the coming generations but the task of an intellectual framework, of intellectualising feminist history and thought. Similarly to the conceptual categorisation and myth-making of modernity, it is vital to define, on women's own terms, a systematic structure of thought which can function as an intellectual and cultural legacy for women of future generations, so they can build from there.

The thoughts in this novel appear in earlier essays in similar words, so a sense of echo, or amplification, emphasizes the importance for Dohm's generational thinking. In the already cited essay Die wissenschaftliche Emancipation der Frau, we find the category of the pioneers already in 1874 :

Wir leben in einer Zeit des Ueberganges. Nur eine geringe Zahl von Frauen hat bis jetzt die Bahn der Emancipation beschritten (das Contingent, das Deutschland gestellt hat, ist verschwindend klein). Ein Theil dieser Frauen sind muthige Vorkämpferinnen, Pioniere, die in einen Riß springen, die eine Kluft füllen, auf daß folgende Generationen bequem darüber fortschreiten können. ${ }^{20}$

\footnotetext{
${ }^{19}$ Dohm, Christa Ruland, pp. 125-26.

${ }^{20}$ Dohm: Die wissenschaftliche Emancipation der Frau, p. 51 (see CD-ROM Deutsche Literatur von Frauen, p. 15865).
} 
In her later collection of essays Die Antifeministen (1902), Dohm again expresses her hope for the future of the women's movement: time is inevitably on the side of progress towards improvement of humanity, and future generations will undoubtedly reap the benefits of the fights begun by the First Wave. Here, though, the image of Moses is only implied and accompanied by sadness about the inevitable progress of time which will cut off the FirstWave generation from enjoying the fruits of their struggles:

Revolutionen werden nicht mit Rosenwasser gemacht. Es braucht aber nicht gerade Blut zu sein. Die Zeit ist die größte Revolutionärin; nur schreitet ihr eherner Schritt langsam, langsam aufwärts.

Und das ist die tiefe Tragik der Vorausdenkenden, daß sie ihre Zeit nie erleben, das heißt, sie kommt erst, wenn sie gegangen sind. ${ }^{21}$

While Dohm employed a programmatic rhetoric in the aid of a generational project of intellectual, theoretical framework-formation for German feminism, she was also critical of its development, or the lack thereof, by her fellow contemporary bourgeois feminists. For Dohm, the main political focus of the women's movement should have been suffrage, and all the other legal and social changes her contemporaries campaigned for would inevitably follow after suffrage was achieved:

Die unmittelbaren, praktischen Folgen des Stimmrechts sind vielleicht nicht die wichtigsten. Die Hauptsache aber ist dies: die Gewährung des Stimmrechts ist der Schritt über den Rubikon. Erst mit dem Stimmrecht der Frauen beginnt die Agitation für jene großartigen Reformen, die das Ziel unserer Bestrebungen sind. Die Theilnahme am politischen Leben macht alle anderen Fragen zu offenen. ${ }^{22}$

However, her contemporaries' unwillingness to campaign for the right to vote and focus instead on reforming women's legal status and education 'from the outside' was a source of great frustration for Dohm. In a private letter to fellow writer Amely Bölte (1811-1891) from 1880 she expresses her dissatisfaction very bluntly:

Was Ihre Äußerungen über den Rand [the radical minority; BM] der Frauenfrage in Deutschland betrifft, so stimme ich Ihnen vollkommen bei, ich meine aber, daß die

\footnotetext{
${ }^{21}$ Dohm, Die Antifeministen, p. 166 (see CD-ROM Deutsche Literatur von Frauen, p. 16376).

${ }^{22}$ Hedwig Dohm, Der Frauen Natur und Recht. Zur Frauenfrage zwei Abhandlungen über Eigenschaften und Stimmrecht der Frauen (Berlin: Wedekind \& Schwieger, 1876).
} 
Frauen vielleicht eine größere Schuld trifft als die Männer und zuweilen kann ich mich des Gedankens nicht erwehren, daß die deutschen Frauen in Bezug auf ihre Intelligenz hinter den Frauen der anderen Kulturländer zurückstehen. Ich bin längst resigniert. In letzter Zeit beschäftige ich mich wenig mit der Frauenfrage, weil ich den unfruchtbaren Zorn scheue, der mich jedesmal ergreift, wenn ich auf dieses Gebiet meine Gedanken lenke. ${ }^{23}$

Although Dohm placed her trust and optimism in future feminist generations, she apparently could not help but perceive a feeling of circularity in the presumed linear model of historical and social progress when she wrote:

Man kommt sich auf dem Gebiet der Frauenfrage immer wie ein Wiederkäuer vor. Es liegt an der Taktik unserer Gegner, die wieder und wieder die selben Behauptungen aufstellen, unter absoluter Ignorierung unserer Widerlegungen, und uns damit nötigen das zehnmal Gesagte noch einmal zu sagen. ${ }^{24}$

While Dohm ascribes the necessity to chew over the same things again and again to the ignorance, the wilful ignorance, of opponents of the women's movements, one cannot help but think of the equally wilful ignorance of later generations of German feminists who appear to be not even aware of the texts, concepts, and theories of their predecessors, thereby having to start their discourses from scratch, and, as a necessity, in reaction to hegemonic discourses, rather than in a pro-active, defining way on their own terms. Fortunately, at least one of Dohm's ideas appears to be consistently true, even if it means that the same topics and battles have to be fought again and again: 'Die Welt ist ein Riesenphonograph. Ideen, die einmal hineingesprochen, bleiben unauslöschlich darin haften. Sie klingen wieder, klingen wieder'. ${ }^{25}$

Dohm continued to write after this period of resignation following the radical and provocative essays of the 1870s. In the 1890s she began writing the aforementioned trilogy of novels and did not stop writing essays, articles, novellas, and dramatic dialogues until her death in 1919. Although Dohm still wrote in support of the women's movement and especially the radical faction of it, she also began to comment on the development of the movement in terms of theoretical categories. In contrast to Otto-Peters for example, who

\footnotetext{
${ }^{23}$ Hedwig Dohm, Briefe aus dem Krähwinkel (Berlin: trafo, 2009), p. 34.

${ }^{24}$ Dohm, 'Gesichtspunkte für die Erziehung zur Ehe',Sozialistische Monatshefte, 13 (1909), 639 -45 (p. 640) http://library.fes.de/cgi-bin/digisomo.pl?id=03053\&dok=1909/1909_10\&f=1909_0639\&l=1909_0645 (last accessed 26 July 2015)..

${ }^{25}$ Dohm, Die Antifeministen, p. 166 (see CD-ROM Deutsche Literatur von Frauen, p. 16376).
} 
mostly commented on material achievements and improvements, Dohm focused on shifts in social attitudes and on the development of a wider feminist thinking which was aware of gendered, political implications in day-to-day language, behaviours, or attitudes. An example of this is the essay collection Die Mütter, in which Dohm deconstructs the very notion of motherliness (that is, physical motherhood and its idealisation) as something male-defined, and thereby shows that even the dominant discourse of the women's movement is still stuck in this logocentric ideology, since it has been unable to define women's involvement in the public sphere in women's own terms. Dohm's main criticisms, across the essays, aim at demystifying the ideology that a patriarchal society has constructed around the physical process of motherhood and its political and social implications:

Weil die Frauen Kinder gebären, darum sollen sie keine politischen Rechte haben. Ich behaupte: weil die Männer keine Kinder gebären, darum sollen sie keine politischen Rechte haben und ich finde die eine Behauptung mindestens ebenso tiefsinnig wie die andere. $^{26}$

Having said that, Dohm does not position herself explicitly in either discourse of motherliness, that is, while she writes at great lengths about the idealized imagery of motherhood and the social restrictions it contains, she does not link this to either the already mentioned radical feminist discourse nor to the 'extended motherliness' discourse. Implicitly, her essays seem to support the radical cause for women's control over their reproductive rights, while some instances of her novels, particular the ending of Christa Ruland (1902), ${ }^{27}$ clearly tie in with the idea of a social rather than physical mothering. I have shown elsewhere that Dohm was sceptical about a too literal interpretation of women exerting political influence through the means of bringing forth and educating the next generation, that is, their own children, by using her novels to explore how this form of generational work perpetuates, rather than challenges, the political as well as gender-norms-related status quo. ${ }^{28}$ Dohm's concept of productive generational work is more focused on intellectual legacies rather than physical or biological ones, the main priority being the gaining of suffrage on the political side, from which the resolution of many other issues will follow, and on the internal, feminist side, the formation of a feminist intellectual tradition which is able to encompass many relevant discourses to be passed on to and through the following generations.

\footnotetext{
${ }^{26}$ Dohm, Der Frauen Natur und Recht, p. 124 (see CD-ROM Deutsche Literatur von Frauen, p. 16105).

${ }^{27}$ Dohm, Christa Ruland (Berlin: trafo, 2008).

${ }^{28}$ See Mikus, 'Children of the Revolution?'.
} 
While Dohm primarily represented an optimistic stance towards the future of feminist generations, she was not blind to the practicalities and time-consuming changes ahead of the early feminists, and occasionally she voices in her texts the lamentations of the older generation, among which Dohm counted herself, when looking at representatives of the younger generations:

Viele von den höherbegabten Frauen der älteren und allerältesten Generation blicken an der Schwelle des Todes mit schaudernder Verwunderung, mit tödlicher Bitterkeit auf ein Leben zurück, das nicht ihr eigenes Leben war, und klagend senken sie das müde weißte Haupt: „Weh“ mir, daß ich kein Enkel bin - nein - daß ich kein Urenkel bin, denn auch die Enkelinnen von uns Alten kämpfen noch um ihre Eigenheit““. ${ }^{29}$

However, despite this occasional pessimism with regard to the missed chances of her own generation, Dohm's usage of the generational image is a positive one: in her vision of forming an intellectual tradition, the term 'generation' is meant in the sense of succession, a united (not necessarily unified) assembly of history of thought by women for women, and through women for the whole of society. While Dohm takes up the topic of generational quarrels between mothers- and daughters-in-law, and also does so in Die Mütter, it is to deconstruct how this intergenerational sniping benefits the dominant system and prevents a productive exchange and collaboration between generations of women. In Dohm's thought, therefore, the optimistic idea of the generation is explicitly to be kept free of intergenerational quarrels and is predestined to form collaborations between the feminist generations.

II

\section{CONTEMPORARY GERMAN FEMINISMS THROUGH A COMPARATIVE LENS}

This section of the article reflects on the narratives told about feminist legacies by new popular feminist texts in Germany and maps these against a broader backdrop of narratives from recent Anglophone texts. The volumes selected for discussion, whose authors were all born between 1970 and 1983, include Jana Hensel and Elisabeth Raether's Neue deutsche Mädchen (2008) and Susanne Klingner, Meredith Haaf, and Barbara Streidl’s Wir AlphaMädchen: Warum Feminismus das Leben schöner macht (2008). I also refer to Thea Dorn's Die F-Klasse: Wie die Zukunft von Frauen gemacht wird (2006), Sonja Eismann’s Hot Topic:

\footnotetext{
${ }^{29}$ Dohm, Die Mütter (Berlin: Fischer, 1903), Chapter 3. Accessed online at http://gutenberg.spiegel.de/buch/die-

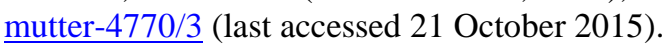


Popfeminismus heute (2007), and Mirja Stöcker's Das F-Wort: Feminismus ist sexy (2007). I have chosen these works as they constitute a striking publishing phenomenon which prompted, as Margaret McCarthy notes in this issue, vigorous public debate around the year 2008 about the role of feminism in contemporary Germany. The fact that cognate phenomena occurred simultaneously on the American and British publishing markets invites a comparative approach to the investigation of this moment of renewed popular feminist debate. Perhaps unsurprisingly in a contemporary Western context characterized by the speed and convenience of global communication channels, new popular German feminism shares many commonalities with its Anglo-American counterparts. These include their sustained interest in the representational politics and feminist potential of popular culture, the question of sexuality as an arena of agency and self-expression, ${ }^{30}$ and the relevance of established domestic feminisms for younger women.

Such synchronicity between German, US, and UK feminist contexts warrants examination for several reasons. First, the historical, cultural, and linguistic links which bind the US and the UK have generated a long-standing dialogue between feminist thinkers in those contexts, to the extent that 'Anglo-American' remains a term which has currency in international feminist discourse. The influence of Anglo-American feminism on German feminist movements has been well documented. ${ }^{31}$ Yet commentators note the cultural specificities which mark the second women's movement in Germany as distinct from, if influenced by, Anglo-American feminist discourse. ${ }^{32}$ Comparing Germany with Britain and the US will therefore provide insight into the specificities of current German understandings of feminist legacies. Second, these three countries represent a fruitful comparative constellation due to the political and economic resonances they have shared since the ascendance of so-called 'Third Way' politics in the Clinton-Blair-Schröder era. Given the emphasis Georgina Paul and Margaret McCarthy place in their contributions to this issue on the role played by neoliberal ideologies in late-twentieth- and twenty-first-century feminisms, comparing three culturally and linguistically variant contexts which have nevertheless adopted similar political and ideological trajectories yields compelling insights into the

\footnotetext{
${ }^{30}$ See Katja Kauer's article in this issue for a detailed analysis of pop-feminism and sexuality.

${ }^{31}$ See Edith Hoshino Altbach et al. (eds), German Feminism: Readings in Politics and Literature (Albany, NY: State University of New York Press, 1984); Myra Marx Ferree, Varieties of Feminism: German Gender Politics in Global Perspective (Palo Alto: Stanford University Press, 2012); Emily Spiers, 'Reading the Wave: Transnational Discursive Transactions and Reception in West German New Feminism' (University of Oxford, M.St. dissertation, 2011).

${ }^{32}$ See Ferree, Varieties of Feminism. See also Charlotte Woodford's article in this issue.
} 
interplay between the global and the local in political and economic paradigms. ${ }^{33} \mathrm{~A}$ comparative approach will therefore generate useful insights into the specificities of German feminism in a contemporary local setting and also reveal the extent to which new German feminisms align with broader feminist narratives in the Western context.

In her 2011 volume Why Stories Matter: The Political Grammar of Feminist Theory, feminist scholar Clare Hemmings undertakes an insightful analysis of the kinds of stories British and American feminists tell about feminist history in the West. Who does or does not get cited during the construction of feminist narratives concerning the past, present, and future of feminism, she asserts, constitutes a politically charged issue. Citational practice, contends Hemmings, relates directly to immediate tensions playing out in the contextual 'now'. ${ }^{34}$ Affective displays and elicitations performed by the narrators of these stories, as well as the deployment of generational motifs, equally impact upon the construction - and also destruction — of modes of feminist being in the present.

Drawing on Hemmings' thinking, I begin with the following observations relating to the German feminist texts under discussion. First, their authors generally avoid glossing a domestic feminist tradition before 1968, a phenomenon which contrasts with the practices revealed by cognate texts in the Anglophone context. Second, the mode of feminist thinking associated with the '1968 generation' in Germany frequently becomes the object of affective displays of frustration and even intense dislike, as new German feminists accuse their forebears - Alice Schwarzer, in particular — of prohibiting the progress they seek to secure. These affective displays occur within the text and function to distance the narrators (and implicitly their readers) from the 'generation' of feminists preceding them. The authors often vent their frustration without directly referencing the original textual material penned by the objects of their criticism, a strategy which elevates their critique to a commonly shared truth and creates a curiously imbalanced bibliography in terms of temporal range. Third, new German feminist texts enact a spatial, as well as temporal, distancing from feminist precursors in Germany through citational practices which draw on Anglo-American discourse rather than domestic or otherwise European sources (the exceptions being French feminists Simone de Beauvoir and Luce Irigaray).

\footnotetext{
${ }^{33}$ See also Hester Baer, 'German Feminism in the Age of Neoliberalism: Jana Hensel and Elizabeth Raether's Neue deutsche Mädchen', German Studies Review, 35.2 (2012), 355-74 .

${ }^{34}$ Clare Hemmings, Why Stories Matter: The Political Grammar of Feminist Theory (Durham; London: Duke University Press, 2011), pp. 22-23.
} 
By analysing the ways in which American, British, and German popular feminist texts narrate feminist history, I aim to reveal, first, how these narratives overlap and, second, the implicit assumptions they make about who constitutes the 'proper' subject of feminism and the beneficiary of feminist legacies. My intention is to illuminate some of the negative implications of such superficially contesting narratives. Following Hemmings, it is vital to scrutinize and untangle these narratives because they all too often 'intersect with wider institutionalizations of gendered meanings'. ${ }^{35}$ By this I mean that feminist narratives that portray types (whether older or newer) of feminism as anachronistic often prove amenable to wider postfeminist discourse as it manifests in public representations of gender equality in the West, which also depict 'feminism' as a now anachronistic phenomenon. ${ }^{36}$ The risk arises that such struggles align with wider social and discursive forces that threaten the continued processes of debate and exchange characterizing feminist movements and their legacies.

I explore the wider uses of Hemmings' methodology by applying it to popular, rather than academic, feminist publications and to volumes outside the Anglophone market. While such popular books do not normally make use of an academic apparatus including footnotes and a bibliography, most of them do provide lists for further reading, and they all reference previous feminist thinkers, and engage with feminist theory. This involves an active process of selection which makes the texts eligible for an analysis of their citation practices. I examine two of the three types of story Hemmings identifies - the narratives of 'progress' and 'loss' - which each match the ideological view-point of its narrator. The narrative of progress proclaims a departure from what its proponents claim was the admittedly effective but fundamentally unenlightened thinking associated with the second wave. Tempered gratitude is expressed for their galvanizing efforts, but progress narratives generally go on to depict second-wave feminism as an essentialist, universalizing discourse located firmly in the past. Poststructuralism, postcolonialism, and gender studies have since enacted a welcome intervention, effecting the transition from essentialism to accounts of intersectional, fluid identities in which differences between women are both respected and celebrated. Hemmings glosses this story of progress in the following manner:

We used to think of "woman" or feminism as a unified category, but through the subsequent efforts of black and lesbian feminist theorists, among others, the field has diversified and feminism itself has become the object of detailed critical and political

\footnotetext{
${ }^{35}$ Ibid., p. 1.

${ }^{36}$ Hemmings, Why Stories Matter, p. 137.
} 
scrutiny. Far from being a problem, difference within the category “woman”, and within feminisms, should be a cause for celebration. [...] Since "woman" is no longer the ground of feminism, and the relationship between the subject and object has been destabilized, an intellectual focus on gender or feminism alone may indicate an anachronistic attachment to false unity or essentialism. ${ }^{37}$

The narrative of loss, on the other hand, characterizes recent feminist history in terms of the perceived loss of unified political engagement in the face of the fragmentation of categories initiated by poststructuralism, which privileges cultural over materialist critique. Hemmings third story — the narrative of return — reclaims an embedded feminist materialism after weathering the period of perceived postmodern distraction; for, so the narrative goes, those materialist theories might still have something to offer despite the 'valuable critiques of essentialism' they were exposed to. ${ }^{38}$ What is striking, but which space precludes me from exploring here, is that return narratives appear hitherto absent in the German pop-feminist context, partly because German pop-feminists tend to draw predominantly on third-wave feminist thinking, which they associate with the US feminist context of the 1990s, and not on later theories associated with new materialist feminisms (Anglophone or otherwise).

\section{Progress Narratives}

The American writer Jessica Valenti (b.1978), founder of Feministing.com, is an important figure in US popular feminism, and her work resonates with the tone and content of the German Alpha-Mädchen’s volume I discuss below. Valenti’s Full Frontal Feminism (2007) constitutes a narrative of progress that historicizes second-wave feminism in the same way as it does the first wave, providing an even-handed three pages each of historical gloss. Yet, Valenti, a self-professed third-wave feminist, continually depicts this historical feminism as encroaching on the present, through the existence of 'cliquey' national organizations like the National Organization for Women, in which the 'same people who were running shit back then are running it now. (Time to pass the torch, ladies!) ${ }^{39}$ Such organizations 'often don’t

\footnotetext{
${ }^{37}$ Hemmings, Why Stories Matter, pp. 3-4.

${ }^{38}$ Hemmings, Why Stories Matter, p. 4.

39 Jessica Valenti, Full Frontal Feminism: A Young Woman's Guide to Why Feminism Matters (Berkeley: Seal Press, 2007), p. 166.
} 
represent the reality of the movement' due to their 'inability to recruit younger women and keep them interested'. ${ }^{40}$ Valenti continues:

So while I'm going to do my best to give you some background about how we got where we are today, I want to spend more time talking about where we're going. Because as important as feminism's history is, and as proud as we should be of our foremothers, the more important question is about how we move forward. Together. ${ }^{41}$

Valenti's comments reveal her understanding of US feminism as developmental along generational lines. The metaphor she uses is of the linear progress of the Olympic torch being passed down from the 'ladies' of the second wave (transformed into an anachronistic presence through the genteel register of the operative word 'ladies') to the younger women who, it is implied, constitute the 'reality' of the movement. Alongside this implicitly ageist claim, albeit tempered by the display of humour in parentheses, Valenti's words perform an affective display of dutiful acknowledgment ('I'm going to do my best') as well as performing the perlocutionary act of encouraging pride in a shared history. Yet these displays do not diminish the impact of the generationally distancing 'foremothers', who, anachronistically, are still 'running shit now'. Combined with the syntactical hierarchy produced by the anaphoric use of 'as', pride and importance become subsumed under the 'more important question' of moving forward. Due to the placing of the second wave firmly in the past, the tag 'together' becomes ambiguous. Does Valenti wish to suggest a crossgenerational future? Or is she in fact referring to a future 'we' of 'young feminists', the target audience of her volume?

Despite her acknowledgement of feminist predecessors, Valenti continually refers to a history of race and class-based exclusions practiced by first- and second-wave feminists and those who write about them. 'In fact', Valenti observes, 'the most famous suffragettes turned out to be a tad racist. ${ }^{42}$ To support this claim, Valenti provides a footnote in the form of a Wiki link, which unfortunately leads to a generic web page lacking the quotation she cites. The quotation is purported to stem from Elizabeth Cady Stanton, renowned American suffragist, and is intended to provide further evidence of Stanton's opposition to the Fourteenth and Fifteenth Amendments, which would have provided African-American men

\footnotetext{
${ }^{40}$ Valenti, Full Frontal Feminism, p. 166.

${ }^{41}$ Valenti, Full Frontal Feminism, pp. 166-67.

${ }^{42}$ Valenti, Full Frontal Feminism, p. 168.
} 
with voting rights. Although Stanton's speeches of the time do betray classist and racist thinking, nowhere does Valenti mention Stanton's long-standing work with the abolitionist movement, nor that Stanton's opposition was based on her conviction that these amendments should not be passed before voting rights for women, both black and white, were also included. ${ }^{43}$ Valenti also fails to mention members of the American Woman Suffrage Association, who disagreed with Stanton and Susan B. Anthony's strategy. (Anthony, a fellow suffragist, joined Stanton in opposing the Amendments.) Instead, Valenti continues to make racism and classism the defining characteristic of both the first and second waves by spending the majority of her glosses discussing it. This strategy is intended to counteract the effects of what Valenti claims constitutes 'standard' feminist historiographies: 'The part of the feminist movement that has been most talked about [...], most written about, and most paid attention to is the rich-whitey part. ${ }^{44}$ By omitting any citational evidence for her claim, the reader understands Valenti's comment to be irrefutable, a commonplace no longer worthy of justification. Valenti then provides one unreferenced example of this 'rich-whitey' behaviour:

For example, back in the '60s and '70s, white middle-class feminists were fighting for the right to work outside the home, despite the fact that plenty of not-so-privileged women were already doing that. Because they had to. Even now, issues of race and class come up in feminism pretty often. But unlike in days of yore, now they're being addressed. $^{45}$

This excerpt, while seeking to demonstrate the progress which has been made from a privileged, universalizing first- and second-wave feminist past, to an intersectional, more politically astute third-wave present, in fact achieves the opposite. First, her sweeping, unqualified language universalizes the second-wave feminist subject in terms of temporality, race, class, and issues. This subject, her language suggests, existed exclusively in those 'days of yore', from the 1960s-1970s (despite still running NOW today); she was exclusively white and middle class; and the only issue worth mentioning was the 'right to work outside the home'. The most pernicious aspect of this statement,

\footnotetext{
${ }^{43}$ See Judith Papachristou, Women Together: A History in Documents of the Women's Movement in the United States (New York: Knopf, 1976).

${ }^{44}$ Valenti, Full Frontal Feminism, p. 10.

${ }^{45}$ Ibid.
} 
however, is the slippage between the word 'feminist' used in relation to white middleclass women and 'women' used in relation to 'not-so-privileged' subjects. The shift from 'feminist' to 'women' then becomes contingent upon divisions along the lines of race and class, implying that feminism belonged only to the rich, white subject, whose focus should have been on the proper object of feminism (the 'not-so-privileged' woman), but was not. In contrast, the racialized, classed 'other' labours on in an unenlightened pre-feminist state, an implication that betrays Valenti's ignorance of a tradition of black and Marxist feminist theory in the US, associated with activists and writers such as Claudia Jones, Frances M. Beal, Angela Davis, Audre Lorde, Joan Didion and Barbara Ehrenreich, which was also vibrant in the 1960s and 1970s. This elision of a concomitant feminist history throws doubt on Valenti's final comment that now issues of race and class are 'being addressed'. For, if Hemmings' contention that historical stories reveal current tensions obtains, this striking slippage also delineates who Valenti views to be the 'rightful' feminist subject and object today.

Valenti's strategy for addressing the issues appears to be based on a performative act of homogenizing then jettisoning first- and second-wave feminism entirely rather than engaging textually with the voices Valenti claims have been ignored. She does in fact do this to some extent, mentioning the names of Angela Davis and Alice Walker and even 'lesbian theory' as part of her fifteen-line list of 'cool stuff that came out of the second wave'. ${ }^{46}$ Otherwise, her engagement with intersectionality, classism, and homophobia is restricted to an eight-page 'Quick Academic Aside' towards the end of the volume rather than emerging in her central historical analyses.

Valenti's progress narrative resonates with that of the German writers Susanne Klingner (b.1978), Meredith Haaf (b.1983), and Barbara Streidl (b.1972) in their 2008 essayistic volume Wir Alpha-Mädchen, and with Elisabeth Raether (b.1979) and Jana Hensel’s (b.1976) 2008 autobiographical text Neue deutsche Mädchen. Unlike Valenti, these authors single out one central second-wave protagonist responsible for the anachronistic character of contemporary feminism in Germany, Alice Schwarzer (b.1942), described by the alpha girls as the 'Oberboss des Feminismus'. ${ }^{47}$ Their texts single out Schwarzer's position and person for criticism while simultaneously advocating renewed engagement with feminism. These authors, in their early thirties when the texts were published, seek to attract a

\footnotetext{
${ }^{46}$ Valenti, Full Frontal Feminism, pp. 171-72.

47 Susanne Klingner, Meredith Haaf and Barbara Streidl, Wir Alpha-Mädchen: Warum Feminismus das Leben schöner macht (Hamburg: Hoffmann und Campe, 2008), p. 196.
} 
younger readership, which explains to some extent their decision to self-identify as Mädchen. As 'girls' they distance themselves linguistically and ideologically from a Frauenbewegung now perceived as anachronistic, and from the negative stereotypes of second-wave feminists which have flourished in postfeminist popular culture. ${ }^{48}$ Importantly, these new volumes eschew the term postfeminism, their authors reclaiming a fundamentally feminist identity while modifying it to suit their purposes. (They write, for example, not as 'feminists' but as 'alpha’ or 'neue’ 'Mädchen'.)

In unequivocal language, the new German girls place Schwarzer firmly in the past: 'mehr als das, was sie bis jetzt erreicht hat, wird diese [Schwarzer's] Generation nicht erreichen. Die Zeit hat sie eingeholt, ihre Rhetorik ist oll, Alice Schwarzer und ihre Frauen sind Historie geworden.' ${ }^{49}$ The non-standard term 'oll' here functions like Valenti's use of 'yore' and 'ladies' to 'other' the second wave linguistically by implying it is irrelevant. Following Hemmings, their generational logic constructs others, in this case Alice Schwarzer and her 'Frauen', as 'less invested in feminism by privileging time over context'. ${ }^{50}$ In this excerpt, what matters is that 'die Zeit hat sie eingeholt' rather than the matter of contextually based oppositions. When the Mädchen then claim that '[i]hre Sache ist ihnen entglitten. Sie hat sich verselbstständigt', they echo Valenti's claim that the feminist elite, consisting of perseverant second wavers, no longer represents the 'reality' of the movement, by which they mean the 'reality' of young women's lives. The impression Schwarzer makes on the new German girls, 'als wolle sie mit aller Kraft verhindern, dass man ihr die Deutungsmacht aus der Hand nimmt', evokes the reluctance observed by Valenti amongst established second wave feminists in the US to 'pass the torch' on to the next generation. ${ }^{51}$

The term 'generation' features prominently within Wir Alpha-Mädchen and Neue deutsche Mädchen, as well as in statements on their first-edition fly covers, respectively: '[e]ine neue Generation von Feministinnen meldet sich zu Wort' and '[s]elten war eine Generation der 30-Jährigen so frei, sich selbst neu zu erfinden’. This rediscovery is necessary because the new German girls 'ärgern sich über die Selbstinszenierung des "EmmaFeminismus”, der so alt ist wie sie'. This reference to Alice Schwarzer's feminist publication Emma makes it clear from the start who the target of critique will be, and the direct comparison of the authors' age with the magazine's drives home the message that 'Emma-

\footnotetext{
${ }^{48}$ But it also infantilizes these thirty-something authors and their readers and aligns their feminism with wider commercial culture which idealizes female youth over maturity.

49 Jana Hensel and Elisabeth Raether, Neue deutsche Mädchen (Reinbek bei Hamburg: Rowohlt, 2008) p. 14.

${ }^{50}$ Hemmings, Why Stories Matter, p. 150.

${ }^{51}$ Hensel and Raether, Neue deutsche Mädchen, p. 14.
} 
feminism' should be considered anachronistic. Simultaneously revealed, however, is also an ageist presumption about the 'rightful' subject of contemporary feminism, that is, a young woman rather than a woman still behaving as if society were the same as 'in den sechziger Jahren'. ${ }^{2}$

The new German girls’ impulse to highlight Schwarzer’s anachronism, however, also leads them to reveal their assumptions about the rightful object of German feminism. They take issue, for example, with Schwarzer's focus on ““[...] das Allerschlimmste, was einem passieren kann”': including genital mutilation, stoning, sexual violence, and rape. They take this as evidence for Schwarzer's lack of knowledge about young women in Germany, '[d]enn das Allerschlimmste passiert selten, und meistens passiert es nicht uns, es passiert woanders'. The reference to genital mutilation and stoning implicitly locates this 'woanders' in a Southern and/or Eastern global context. This re-directs attention from 'advanced' Western cultures to pre-feminist, 'developing' cultures and the figure of the oppressed subaltern woman, in particular, as the 'rightful' object of feminist engagement. Ironically, this move mirrors Schwarzer's own tendencies in Die Antwort (2007), in which she responds, amongst other things, to 'neues Mädchengeplapper' and the protagonists of a " "neue[r] Feminismus", 53 Throughout her volume, Schwarzer approaches what she calls the 'Entwertung der Frauen durch politisierten Islam' by comparing it to the situation faced by women in the West fifty years ago: 'Denn es ist kein halbes Jahrhundert her, da herrschten bei uns noch ganz ähnliche Verhältnisse. ${ }^{54}$ This approach creates a problematic temporal and spatial hierarchy which places the West at the pinnacle of civilization and Western feminism as one of its defining attributes. I mention this in order to demonstrate how such superficially opposing types of feminist narrative share commonalities which the generational motif conceals.

In terms of affective displays of frustration with the anachronistic state of contemporary feminism, the new alpha girls match Valenti’s full-frontal feminism. This surfaces when the authors discuss their perception of the prohibitive stance of second-wave feminists, which, they claim, also rotates around the question of who rightfully constitutes a feminist subject. Valenti views the problem to be one of 'infighting — particularly of a generational kind — about what a "real" feminist is'. ${ }^{55}$ The alpha girls, too, claim feminism

\footnotetext{
52 Ibid., p. 14.

${ }^{53}$ See the back cover of Alice Schwarzer, Die Antwort (Cologne: Kiepenheuer \& Witsch, 2007) and p. 182.

${ }^{54}$ Schwarzer, Die Antwort, p. 9.

${ }^{55}$ Valenti, Full Frontal Feminism, p. 174.
} 
has not faded into the postfeminist background 'weil er nichts mehr zu tun hat', but due to 'die Grabenkämpfe und die Rechthaberei’. They continue:

Unter politisch Aktiven gibt es immer Menschen, die ihre eigenen Überzeugungen zu allgemeinen Wahrheiten erheben. [...] Und weil das zentrale Thema der Neuen Frauenbewegung letztlich das Privatleben war, schadete dieser Reflex der Entwicklung des Feminismus ganz besonders. Denn wenn ständig eine erzählt, wie alle anderen richtig zu leben haben, dann nervt das. ${ }^{56}$

Note how in this excerpt the non-specific and gender-neutral 'Menschen' in the third line becomes a very pointed 'eine' in the last sentence, presumably directed at Alice Schwarzer herself. Valenti often raises the affective bar through the use of expletives. At one point she exclaims, for example: '[h]onestly, I'm so fucking sick and tired of people telling me how to be an appropriate feminist - or what a feminist looks like'. ${ }^{57}$ In both passages above, the targets of the authors' frustration are implied but not referenced directly. In the new-alphagirls’ texts, glossing Schwarzer's proclivities occurs without direct citation of her primary material, which raises the observations to commonly shared truths, and, through perlocutionary force, encourages the reader to share this affect of frustration.

Celebratory affect is equally important in a progress narrative. The alpha girls establish this immediately with their inclusive claim that 'Alpha-Mädchen sind wir alle. Nicht nur die Autorinnen dieses Buches, sondern alle jungen Frauen, die mitdenken und Ziele haben; die sich für die Welt interessieren und frei und selbstbestimmt leben möchten, jede nach ihrer Art — das sind wir Alpha-Mädchen’. ${ }^{58}$ A closer look at this passage reveals the work done to generate a sense of affiliation between reader and type of feminism through affect and slippery logic. Beginning with an open invitation that claims that this feminism is for 'alle', the type of subject for whom this feminism is relevant becomes incrementally narrower, imbued with positive attributes and set in direct opposition to a feminism which incorporates older women’s perspectives. ‘Alle’ becomes ‘jung[e] Frauen’, then young women who also 'mitdenken und Ziele haben', then young women 'die sich für die Welt interessieren und frei und selbstbestimmt leben möchten’. These positive, albeit vague, attributes constitute desirable characteristics a reader may feasibly already associate or wish

\footnotetext{
${ }^{56}$ Haaf, Klingner, and Streidl, Wir Alpha-Mädchen, p. 194.

${ }^{57}$ Valenti, Full Frontal Feminism, p. 174.

${ }^{58}$ Haaf, Klingner, and Streidl, Wir Alpha-Mädchen, p. 7.
} 
to associate with themselves. After all, not being an alpha girl implies being someone who has no goals, or who does not think or act for herself.

Yet in order to construct a persuasive and comprehensively relevant progress narrative, the alpha girls must also perform the same anti-universalizing gesture Valenti performs in relation to third-wave feminism. They do this to signal a move from the universalist identity politics they associate with Schwarzer to a poststructurally inflected politics of difference and intersectionality. As the above excerpt shows, however, the firstperson plural mode of address has already been deployed to perform a celebratory affect which simultaneously blocks access to older women. Implicitly, however, this mode of address also excludes queer, ethically or racially 'other' women. There is a statement on page eight, for example, that some readers 'werden vielleicht die spezifischen Perspektiven lesbischer Frauen oder etwa Migrantinnen vermissen', for these are not addressed in their allegedly all-inclusive feminism. This is why the alpha girls offer the disclaimer that 'dieses Buch hat nicht den Anspruch, sämtliche Sichtweisen zu vereinen' ${ }^{59}$ because they know 'dass nicht alle jungen Frauen in Deutschland gleich leben'. This disclaimer has a similar function to Valenti's critique of first- and second-wave 'rich-whitey' feminist elitism: a professed understanding of difference and intersectionality as constituting a progressive turn in Western feminism relieves the narrators of the burden of engaging fully with its details or its implications within their texts.

Like Valenti, the alpha girls also stress the importance of the theoretical insights provided by 'die Genderforschung' for their own work, by which they mean the differentiation between 'biologischem und sozialen Geschlecht sowie zwischen Geschlecht und Geschlechtsidentität'. ${ }^{60}$ Referring to 'gender studies', as opposed to 'women's studies', in all contexts functions as short-hand for describing the intervention of poststructuralist, queer, and postcolonial feminist critiques, which are portrayed as interrupting the selfabsorbed universalism and essentialism of the second wave. In her work, which does not draw on German feminism, Clare Hemmings notes that Judith Butler's Gender Trouble (1990), in particular, functions as a threshold text in this respect, providing the same kind of short-hand for this shift as does the choice of naming gender studies rather than women's studies. This is particularly the case in the new feminist German texts under discussion. For example, in her contribution to the multi-authored volume Das F-Wort: Feminismus ist sexy, Jenny Warnecke (b.1975) credits Butler with the single-handed dismantling of the category

\footnotetext{
${ }^{59}$ Haaf, Klingner, and Streidl, Wir Alpha-Mädchen, p. 8.

${ }^{60}$ Haaf, Klingner, and Streidl, Wir Alpha-Mädchen, p. 30.
} 
woman, indeed of the subject itself. Warnecke locates the origins of twenty-first-century feminist thinking in Butler's account of the incoherent subject and glosses the latter's impact:

Mitten hinein in dieses Wir-Gefühl hat Judith Butler die Frau als Handlungssubjekt in Frage gestellt und philosophisch kurzerhand aufgelöst, stattdessen hat sie

Bündnispolitik und Netzwerke empfohlen. Aktionen nehmen ihren Ausgangspunkt in einem gemeinsamen Problem und nicht in einer vermeintlichen Geschlechtsidentität. ${ }^{61}$

At another point, she claims that '[d]ie Frau im Plural gibt es nicht mehr. Das ist seit Judith Butlers Buch Gender Trouble klar'. ${ }^{62}$ Butler's deployment as a textual grenade in the new German texts achieves several complex goals at once. First, Butler constitutes a short-hand for the seismic shift in feminist theory which the young authors claim as their inheritance. Second, it distances these authors from their second-wave feminist forebears (and Schwarzer, in particular) theoretically (difference over universalism) and spatially (US over German influence); the mention of Judith Butler, along with other aspects of Anglo-American and French theory, signals a turn away from a domestic tradition of feminist thought. Third, it provides the appearance of a dalliance with queer theory without actually requiring full engagement with its finer details. This is because these volumes are generally entirely heteronormative and draw on Butler almost exclusively for her insights into sex and gender as social constructs and the deconstruction of the category 'women' (as the above passage demonstrates).

In terms of its engagement with feminism before 1968, Wir Alpha-Mädchen is somewhat unusual amongst the new German feminist texts for its extended temporal and spatial range. In Sonja Eismann’s (b.1973) Hot Topic: Popfeminismus heute (2007), Mirja Stöcker's (b.19?) Das F-Wort: Feminismus ist sexy, the Neue deutsche Mädchen volume discussed above, and Thea Dorn's (b.1970) Die F-Klasse: Wie die Zukunft von Frauen gemacht wird (2006), feminist history begins in 1968 (although Dorn does cite Hedwig Dohm's Die Antifeministen (1902) in her bibliography, alongside John Stuart Mill and Harriet Taylor Mill's The Subjection of Women (1869) in German translation). The section in Wir Alpha-Mädchen, entitled 'Eine kleine Geschichte des Feminismus', begins with a

\footnotetext{
${ }^{61}$ Jenny Warnecke, “"Das ist mir zu extrem!” Eine Generationen-Studie’, in Das F-Wort: Feminismus ist sexy, ed. by Mirja Stöcker (Königstein/Taunus: Helmer, 2007), p. 36.

${ }^{62}$ Warnecke, “'Das ist mir zu extrem!”', p. 25. It is striking that the alpha girls focus on Butler and not feminists of colour like Kimberlé Crenshaw or bell hooks who intervened in debates concerning the universal female subject before Butler.
} 
glance at gender inequality in ancient Greece before moving through the Middle Ages, taking in Christine de Pizan’s Le Livre de la Cité des Dames, and the Early Modern period before moving through the French Revolution, Olympe de Gouges, Mary Wollstonecraft's A Vindication of the Rights of Women (1792), the pre- and post-revolution German states, and finally on to fin-de-siècle medical texts such as Paul Moebius' pamphlet 'Über den physiologischen Schwachsinn des Weibes' (1900). This range does not match the young American writer and feminist activist Julie Zeilinger's (b.1993), who spends eleven pages discussing gender inequality from pre-history to the Enlightenment (taking in Mesopotamia, ancient Greece, and Muslim and Christian texts ${ }^{63}$ ), but it does match almost precisely the range and scope of Alice Schwarzer's Die Antwort, which also mentions the key feminist texts present in the alpha girls' volume. Schwarzer's and the alpha girls' trajectories diverge, however, at the moment they reach the first women's movement in Germany, discussed by Birgit Mikus in the previous section.

Although Schwarzer and the alpha girls mention the same feminist protagonists, including Clara Zetkin, Hedwig Dohm, Louise Otto-Peters and Anita Augspurg, Schwarzer exculpates both women in general and radical feminists in particular in terms of their complicity with the National Socialist regime: 'Wie viele in den Führer vernarrte Frauen auch immer gewunken haben mögen: Die Nationalsozialisten waren ein reiner Männerbund, dem Frauen nur in den unteren Rängen dienen durften' ${ }^{64}$ After this brief statement, Schwarzer turns her focus to Anita Augspurg and Lida Gustava Heymann's early call for Hitler's deportation in 1923 and on establishing her own lineage in relation to the 'sogenannt[e] "Radikalen" [...], die antibiologischen beziehungsweise universalistischen Frauenrechtlerinnen', who went into exile before the process of Gleichschaltung began. ${ }^{65}$

In contrast, the alpha girls establish early on their dissatisfaction with the failure of first-wave socialist and liberal feminists to co-operate with each other, citing 'sozial[e] Vorurteile' as one of the reasons. ${ }^{66}$ The alpha girls’ disapproval of class-based prejudice transforms into disappointment when they contrast, in almost breathless tones, the 'nachgerade terroristische Aktionen' of English suffragettes with the '[K]ompromissbereit[schaft]' of German women’s rights activists: instead of bombs and

\footnotetext{
63 Julie Zeilinger, A Little F'd Dup: Why Feminism is not a Dirty Word (Berkeley: Seal Press, 2012), pp. 11-22.

${ }^{64}$ Alice Schwarzer, Die Antwort (Cologne: Kiepenheuer \& Witsch, 2007), p. 15.

${ }^{65}$ Schwarzer, Die Antwort, p. 15. See also Charlotte Woodford's argument in this issue that feminists of the 1970s positioned themselves in opposition to the bourgeois women's movement of the 1900s.

${ }^{66}$ Haaf, Klingner, and Streidl, Wir Alpha-Mädchen, p. 187.
} 
hunger protests, their 'Proteste beschränkten sich zumeist auf Texte, Flugblätter und Unterschriftensammlungen'. ${ }^{67}$ The alpha girls’ most damning critique, however, is foreshadowed by this portrayal of the first women's movement as 'kompromissbereit'. In a few lines of terse prose they criticize the ‘bürgerlich[e] Feministinnen’ who became complicit with the National Socialist regime following the Gleichschaltung. The alpha girls immediately link their condemnation of these first-wave protagonists with renewed criticism of 'manche deutsche Feministinnen', who, even today, 'gern den Eindruck erwecken, der Nationalsozialismus sei ein rein männliches Phänomen gewesen' ${ }^{68}$ This can only be a reference to Schwarzer's passage in Die Antwort, cited above, for they continue in a dialogical fashion with Schwarzer's comments: 'Die Feministinnen, die nicht ins Exil gegangen waren, zogen sich zurück oder gliederten sich in die neuen nationalsozialistischen Frauenorganisationen ein. Sie leisteten keinen Widerstand gegen die Verfolgung und Ermordung ihrer jüdischen Mitbürgerinnen und Mitbürger oder all die anderen Verbrechen, die in dieser Zeit verübt wurden. ${ }^{69}$ German feminism of the early twentieth century, in contrast to Anglo-American feminisms, still cannot escape being read through what Woodford, in her article for this issue, calls the 'lens of hindsight in relation to the trauma of Nazism' - even in the early twenty-first century.

Key to the alpha girls' rejection of Alice Schwarzer, then, is their perception that she places the importance of a shared German feminist history above the recognition of a shared cultural culpability in the past. At its root, this schism also constitutes a theoretical divergence in terms of Schwarzer's equality politics and self-professed universalist stance, which necessitate the construction of a homogenous category 'women'. Exculpating the radicals during the first women's movement's encounter with National Socialism entails exculpating all women to an extent. In this way, the alpha girls' critique of the first German women's movement becomes a critique of established German feminism in the present, just as Valenti's critique of the first-wave's racism and classism constitutes a critique of established US feminism's elitism in the present day. Such critique also signals a theoretical divergence which, in both cases, consists of a move from viewing the category 'women' as essentially unified to recognizing the forced exclusions and inclusions inherent in this kind of thinking.

\footnotetext{
${ }^{67}$ Ibid., p. 187.

${ }^{68}$ Haaf, Klingner, and Streidl, Wir Alpha-Mädchen, p. 188.

${ }^{69}$ Ibid., p. 188.
} 


\section{Loss Narratives}

Loss narratives also constitute a contestation of present-day politics through a processual temporal lens. Affective displays of grief, bewilderment, and anger underlie these narratives in place of the celebratory affect of progress narratives. They both share, however, the tendency to lapse into displays of frustration. Like progress narratives these also tend to focus on the threshold moment of feminist history signalled by the impact of poststructuralism on feminist theory. Most loss narratives, however, mourn rather than celebrate the fragmentation of categories which they perceive has, alternately, led to the disintegration of radical action and feminist solidarity, or to a surfeit of attention paid to culture over materialist economic concerns. There is a sub-strand to such narratives which often aligns this turn with the academization of feminism per se, a process whose completion corresponds with the beginning of the 1990s and heralds, so the narratives go, a withdrawal of feminism from grass-roots activism into the abstraction of the academy. This turn also signals feminist theory's distraction from a focus on the 'reality' of women's lives, prioritizing instead increasingly abstract discussions of 'culture', including questions of social construction, performativity, play, sexuality, and queer theory. This last point of contention is significant due to the generally heteronormative nature of the majority of these popular feminist texts, across all three contexts. It is, however, a striking feature of the loss narratives I discuss that they emerge from a textual corpus which can be described as cross-generational. In the volumes produced by younger authors, in particular, the increasing abstraction of feminist theory is mourned whilst the authors nevertheless draw on the elements of post-1990 theories most amenable to reproduction in a pop-cultural medium: multiplicity, fluidity, performativity, play, and sexuality. In this way narratives which otherwise might be described as progress narratives also contain elements of loss, such as the alpha-girls' volume.

Around the same time as the popular feminist progress narratives appeared in Germany, many articles in the British press that ostensibly called for renewed feminist engagement were often framed in terms of a loss narrative. In a 2006 article examining the political effects of the feminist backlash thirty years after the passing of the Sex Discrimination Act, Zoe Williams (b.1973) asks 'what's happened to all the feminists?' 70 Her article's final rhetorical gesture imagines a shared feminist history in the form of the

\footnotetext{
${ }^{70}$ Zoe Williams, 'Where have all the Feminists Gone?’, New Statesman, 16 January 2006 $<$ http://www.newstatesman.com/node/152342> [accessed 8 April 2015].
} 
relationship between her readership and 'the achievements of yesterday's feminists', but implies that 'we're making no effort to live up to them'. ${ }^{71}$ The writer Courtney E. Martin's (b.1979) article debunking the myth promulgated by Time Magazine in 1998 that feminism is dead is given a title that echoes its target's rhetoric: 'Is Feminism Dead?' Like Williams, Martin also conjures an image of shared feminist history:

What picture pops into your mind when you read the word feminist? Is it a woman layered in petticoats with a big swooping hat, picketing the white house [sic] for her right to vote? Is it Gloria Steinem in her aviator glasses, sleek, straight hair hanging down on both sides of her pretty face? These are the dominant images that so many people associate with feminist history, and for good reason. [...] (Disclaimer: This, of course, is only modern western history I'm referring to. $)^{72}$

This shared history of 'modern western feminism' remains distinctly American, entailing that the future she finally imagines is also an American rather than 'western' one.

In Jenny Turner's (b.1963?) 2011 article analysing the state of feminism in Britain post-London riots, Turner mourns the loss of radical feminist economic politics and a lost spirit of 'solidarity with the less privileged sisters'. The 'white middle-class brigade' has 'drifted so far out of touch' by failing to realize a comprehensively intersectional feminist outlook, and by 'narrowing its focus' to 'culture and consciousness and personal testimony'. ${ }^{73}$ Turner, like Germaine Greer (b.1939) writing in 2014, mourns the loss of radical feminist politics in the youngest generation of feminist activists. Unlike the targets of Williams' piece - the general female population who have profited from the second wave's achievements - Turner and Greer direct their critique to the most recent feminist activists, such as members of activist groups Object and UK Feminista. However, Turner sees them existing on a continuum with the 'white middle-class brigade' of the second wave and beyond, whereas Greer mourns the spirit of lost radicalism, and the subsequent split between feminism as a 'media phenomenon and as an academic discipline. The vast realm of reality that lies between', she claims, 'remains unaffected by either' ${ }^{74}$ Self-

\footnotetext{
71 Zoe Williams, 'Where have all the Feminists Gone?'.

72 Courtney E. Martin, 'Is Feminism Dead?’, New Statesman, 27 November 2007 < http://www.newstatesman.com/blogs/the-faith-column/2007/11/modern-feminism-women-feminist> [accessed 8 April 2015].

73 Jenny Turner, ‘As Many Pairs of Shoes as She Likes’, London Review of Books, 33.24 (2011), 11-15. <http://www.lrb.co.uk/v33/n24/jenny-turner/as-many-pairs-of-shoes-as-she-likes> [accessed 8 April 2015].

74 Germaine Greer, 'The Failures of the New Feminism', New Statesman, 14 May $2014<$ http://www.newstatesman.com/culture/2014/05/germaine-greer-failures-new-feminism> [accessed 8 April 2015].
} 
fashioned as 'this curmudgeonly old feminist', Greer performs a hopeful moment that two recent feminist publications (The Vagenda and Everyday Sexism (both 2014)) suggest that 'there might be sufficient angry women out there and they might be sufficiently angry to bring about actual change'. These two examples of feminism as 'media phenomenon', however, fail to live up to her expectations: 'bitching and whingeing' and 'pimp[ing] for the glamour industry' may 'have their place but without the truth we shall never be free'. ${ }^{75}$

Susan Faludi (b.1959) also makes the connection between generational discord and mass commercial culture. In an in-depth, historiographical essay, Faludi traces the origins of American 'feminism's ritual matricide' to the cultural, socio-economic, and legal shifts occurring at the beginning of the twentieth century 'as an industrialized and urban society, along with all the new educational and economic opportunities that female reformers had fought so hard for, began pulling daughters away from their maternal moorings' ${ }^{76}$ Newly won voting rights combined with the growing force of mass commercial culture 'reversed the authority relationship between mother and daughter ${ }^{77}$ and turned the nineteenthcentury's 'mother-daughter alliance into a nightmare of dysfunction that hounds feminism a hundred years later'. ${ }^{78}$ Faludi contends that

it is hard to see as innocent the consumer indulgence that was implicated in the death of first-wave feminism - especially as the old formula, commercialism versus feminist continuity, is playing out all over again, in academe as well as in the marketplace.

Women's Studies was originally envisioned as the repository of feminist history and memory, where accumulated knowledge would be enshrined in a safe box where future generations could go and retrieve it. That academic mother-lode is in danger of being decommissioned by the increasing disconnect between practical, political feminism and academic feminist theory, and by the rise of a poststructuralist philosophy in gender studies that prefers the deconstructing of female experience to the linkages and legacies

\footnotetext{
${ }^{75}$ Greer, 'The Failures of the New Feminism'.

${ }^{76}$ Susan Faludi, ‘American Electra: Feminism’s Ritual Matricide’, Harper's Magazine (October 2010), 29-42 (p. 36). See Caroline Bland's article in this issue for a detailed analysis of German women’s educational opportunities in 1900 and after World War One.

${ }^{77}$ Faludi, ‘American Electra', p. 38.

${ }^{78}$ Faludi, ‘American Electra’, p. 36.
} 
of women's history and regards generational dynamics, and even the categories of 'woman' and 'man', as artifices to perform. ${ }^{79}$

Perpetually repeating cycles of ritual matricide and the 'shape-shifting contamination of commercialism and commercially infused relativism in feminist activism and scholarship' have, according to Faludi, 'created a generational donnybrook where the transmission of power repeatedly fails and feminism's heritage is repeatedly hurled on the scrap heap. What gets passed on is the predisposition to dispossess, a legacy of no legacy'. ${ }^{80}$ As in the progress narratives discussed in the first section, Faludi portrays poststructuralism as the turning point in feminist history, but one which has aligned with commercial forces and as such contributed to the threatened loss of the 'academic mother-lode', consisting of the accumulated knowledge of the 'linkages and legacies of women's history'. Faludi, who defines herself as falling between second- and third-wave 'generations' and is, as such, an intriguingly placed commentator on generational conflict, nevertheless presents a narrative of loss which makes the specific damage caused to feminism by poststructuralist theory the culprit in the schism between 'practical, political feminism and academic feminist theory' which threatens feminism's demise. As an academic herself, Faludi's negative portrayal of this turn narrows its focus from the target of recent popular feminist texts in the US, Britain, and Germany — academic feminism per se — to poststructuralism, in particular.

Academic feminism as a whole remains the target for the popular texts, however. The British author Ellie Levenson (b.1978), for example, cites a complex statement from Germaine Greer's The Female Eunuch (1970), concluding that '[t]his kind of language is immediately off-putting, not just because I don't have a clue what she is talking about but because the academic framework of this kind of book immediately seems removed from our everyday lives'. ${ }^{81}$ This assessment is somewhat ironic given that Greer herself identifies the same issue in her article discussed above. British journalist and media personality Caitlin Moran (b.1975), too, argues that '[f]eminism is too important to only be $[$ sic $]$ discussed by academics'. ${ }^{82}$

\footnotetext{
${ }^{79}$ Faludi, ‘American Electra’, p. 40. Faludi’s description of Woman’s Studies as a generational project, a repository of feminist knowledge that acts as a legacy, echoes Hedwig Dohm's generational rhetoric, explored by Mikus in this volume.

80 Ibid., p. 40.

${ }^{81}$ Ellie Levenson, The Noughtie Girl's Guide to Feminism (Oxford: One World Publications, 2009), p. 210.

${ }^{82}$ Caitlin Moran, How to be a Woman (London: Ebury, 2011), p. 12.
} 
The German alpha girls also identify a moment of schism and loss in their volume. In the 1990s, they assert, 'Feminismus zog sich immer mehr von der Straße zurück und professionalisierte sich: an den Universitäten oder im politischen Betrieb. In den Köpfen der meisten Frauen und Männer hat sich der unsägliche Postfeminismus breitgemacht’ ${ }^{83}$ In this they again agree with their textual opponent, Alice Schwarzer, who accuses ‘GendertheoretikerInnen’ of abstraction and utopian impracticality: 'Realität jedoch ist, dass wir Männer und Frauen sind [...]. Dieser Realität hat der Genderdiskurs kaum Rechnung getragen, und dadurch leider eher dazu beigetragen, dass die Kluft zur angewandten Frauenforschung und Geschlechterrealität immer größer wurde. ${ }^{84}$ From previous passages in the text where Schwarzer refers rather disparagingly to 'Judith Butler \& Co ${ }^{85}$ it is apparent that Butler is again being used as a shorthand for the turn in feminist theory portrayed as accelerating the split between academic and 'practical, political' feminism.

This cross-section of loss narratives demonstrates a clear consensus on the cause of the dire issues which threaten (or threatened) feminism's demise. This consensus emerges in texts which otherwise position themselves on opposing sides a generational divide. It is also striking that it exists across contrasting cultural and linguistic contexts in the West. The focus on that particular moment of feminist history — the emergence of poststructuralist feminist theory - is also of course a characteristic that loss narratives share with the progress narratives discussed previously. What narratives of progress and loss have in common is their portrayal of contemporary feminism as anachronistic, an effect which is not ameliorated by the narrators' proclamation that they have identified the 'problem' or that they constitute the 'proper' subject of feminism.

What is troubling about this phenomenon is the amenability of such narratives to wider institutionalized discourse on gender equality and postfeminist media portrayals concerning the irrevocable pastness of feminism. Just as many progress narratives problematically consign the history of feminism to the metaphorical dustbin in order to enhance the relevance of their arguments, loss narratives insist upon a future that never happened, and imply that contemporary feminism has 'drifted [...] out of touch'. ${ }^{86}$ The repudiation of feminism as anachronistic coexists with political and institutional forces

\footnotetext{
${ }^{83}$ Haaf, Klingner, and Streidl, Wir Alpha-Mädchen, p. 193.

${ }^{84}$ Schwarzer, Die Antwort, p. 27.

85 Schwarzer, Die Antwort, p. 37.

${ }^{86}$ Turner, ‘As Many Shoes'.
} 
which, in a climate of diminished funding for Higher Education, might seek, for example, to dismantle women's and gender studies departments. Heteronormative loss narratives' critique of poststructuralism often masks an antipathy towards queer theory, and as a result they become commensurable with wider homophobic social narratives. Progress narratives' repudiation of second-wave feminism as anachronistically essentialist and unified, and loss narratives' nostalgic evocation of a shared feminist history also resonate with postfeminist accounts which promulgate the 'fantasy of Western gender equality as already achieved' ${ }^{87}$ Paying attention to the manner in which we, as academics and feminists, tell stories about feminist history, proceeding cautiously in conceptualizations of feminist legacies in local, transnational, and global contexts, therefore 'matters' tremendously.

Notes on Contributors

Birgit Mikus holds a D.Phil from the University of Oxford and is a member of the research staff of the Medieval and Modern Languages Faculty, Oxford. Her most recent publication is the monograph based on her thesis, The Political Woman in Print: German Women's Writing 1845-1919 (Oxford: Peter Lang, 2014).

Emily Spiers is a Lecturer in Comparative Literature and German at the University of St Andrews. Her current research focuses on authorship, globalization, and gender in relation to spoken-word poetry. She is currently preparing her first monograph, Writing the PopFeminist Subject: Alpha-Girl Power across Cultures (Oxford: Oxford University Press, forthcoming, 2016), for publication.

\footnotetext{
${ }^{87}$ Hemmings, Why Stories Matter, p. 138.
} 